\title{
EMBALMING FLUID- A POISONOUS PRESERVATION POTION: EFFECTS ON PULMONARY FUNCTIONS OF STUDENTS
}

\author{
Rashmi Malhotra *1, Rajesh Kathrotia ${ }^{2}$, Arun Goel ${ }^{2}$, Yogesh Singh 2. \\ ${ }^{* 1}$ Department of Anatomy, All India Institute of Medical Sciences, Rishikesh, India. \\ ${ }^{2}$ Department of Physiology, All India Institute of Medical Sciences, Rishikesh, India.

\section{ABSTRACT}

Objective: To explore the effects of acute exposure of embalming fluid fumes on the pulmonary functions in first year medical students.

Materials and Methods: The present study was carried out on 40 healthy, non- smoker first year medical students. The participants were exposed to embalming fluid fumes during cadaver dissection for duration of two hours. Pulmonary Function Tests (PFTs) were performed with computerized spirometer, prior to and immediately after the exposure. The outcome measures were Vital capacity (VC), Forced expiratory volume in 1 second (FEV1), FEV1/ FVC ratio, Peak Expiratory Flow Rate (PEFR), $\mathrm{FEF}_{25-75 \%}$ and subjective symptoms reported by participants.

Results: The acute exposure of embalming fluid fumes was associated with significant decrease in FEV1/FVC ratio and $\mathrm{FEF}_{25-75 \%}$. Rest of the respiratory parameters did not show significant changes. The chief subjective complaints of the participants were pungent smell (92\%), throat congestion (72\%), burning sensation in eye $(70 \%)$, headache $(60 \%)$, nausea (52\%) and rhinorrhoea $(45 \%)$.

Conclusion: The acute exposure to fumes of embalming fluid during cadaver dissection was suggestive of respiratory function dysfunction at the level of mid-airway obstruction and mucosal irritation.

KEY WORDS: Embalming fluid fumes, FEV1/FVC ratio, $\mathrm{FEF}_{25-75 \%}$.

Address for Correspondence: Dr. Rashmi Malhotra, Assistant Professor, department of Anatomy, All India Institute of Medical Sciences, Rishikesh - 249 203, India.

E-Mail: rashmimalhotraaiimsr@gmail.com

\section{Access this Article online}

\section{Quick Response code}

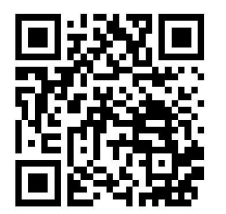

DOI: $10.16965 /$ ijar.2017.187

Web site: International Journal of Anatomy and Research ISSN 2321-4287

www.ijmhr.org/ijar.htm

Received: 17 Mar 2017

Peer Review: 18 Mar 2017

Revised: None
Accepted: 15 Apr 2017

Published (O): 31 May 2017

Published (P): 31 May 2017

\section{INTRODUCTION}

Cadaver dissection is an integral and essential part of first year medical curriculum. To preserve the internal anatomical details and arrest the decay of body, preservatives are routinely applied. The technique of preserving the body is known as 'embalming' and the mixture of fluid applied is known as embalming fluid. The typical embalming fluid used in our department is a mixture of various chemicals like formaldehyde, methyl alcohol, phenol, glycerine, eosin, cetrimide, thymol crystals in water [1-3].

The chief constituent of embalming fluid is formalin as it prevents putrefaction of body and retains the normal anatomical relations. The fixative properties of formalin is attributed to irreversible cross-links formation with macromolecules like proteins, DNA and RNA[4]. Formalin is an aqueous solution of $37 \%$ formaldehyde with low boiling point $\left(-19^{\circ} \mathrm{C}\right)$. It releases irritant, pungent vapours at normal room temperature. In the dissection hall, teaching staff, 
medical students, and technical staff are regularly exposed to irritant formaldehyde vapours during cadaver dissection[5]. However, because of easy availability and low cost, formalin is still the main constituent of embalming fluid across the medical colleges in India.

Research has shown that formaldehyde may cause impairment in pulmonary functions and asthma like reactions in sensitized individuals [6, 7]. The probable mechanism by which it may cause respiratory symptoms is due to high local absorption in the upper and mid-respiratory airways as $95 \%$ of inhaled formaldehyde is rapidly absorbed in the mucosa[8].

In the present study we have explored the effects of acute exposure of embalming fluid fumes on pulmonary functions in first-year medical students and tried to identify the probable anatomical site within the trachea-bronchial tree which could be correlated with pulmonary dysfunction.

\section{MATERIALS AND METHODS}

Objective: To explore the acute effects of two hours exposure of fumes of embalming fluid on pulmonary functions during cadaver dissection.

Study Design: Pre- and post-exposure study.

Participants: Forty first year medical students fulfilled the inclusion criteria and participated in the study. Ethical clearance for the study was obtained from institutional ethics committee for participation of human subjects. We briefed the participants about the study protocol and obtained written informed consent. Only participants without recent history of medical or surgical illnesses were recruited for the study. All participants were exposed to the cadaver dissection and embalming fluid for the first time. Students who were smokers, asthmatics, or had any history suggestive of respiratory or systemic disease, had family or personal history of allergic diseases or suffered from recent upper respiratory illness were excluded from the study.

Intervention: Two-hour exposure of embalming fluid fumes in anatomy dissection hall during cadaver dissection.

Pulmonary Function Tests: PFTs were carried out twice i.e., pre- and post-exposure using computerized spirometer (RMS-helios 401) with built in computer program. Three readings of the PFTs were recorded for each session and the best value out of three was selected for analysis.

Outcome measures: Forced Vital capacity (FVC), Forced expiratory volume in 1 second (FEV1),

FEV1/ FVC ratio, Peak Expiratory flow Rate (PEFR), Forced expiratory flow $\left(\mathrm{FEF}_{25-75 \%}\right)$, Questionnaire related to symptoms (eye, nose, throat and nervous system).

Statistical analysis: All values were expressed as means \pm standard error of the mean. Pre- and post-exposure comparisons were made using paired student's t-test. All analyses were done using SPSS Rel. 13.0 statistical package (SPSS Inc., Chicago, IL, USA). A p-value of $<0.05$ was considered statistically significant.

\section{RESULTS}

The mean age of participants was $18.2 \pm 2.1$ years ranging from $17-21$ year. Sixty four $\%$ participants were male and the $36 \%$ were female. The acute exposure of embalming fluid fumes was associated with statistically significant decrease in FEV1/FVC ratio and $\mathrm{FEF}_{25-75 \%}$ and no changes in FVC, FEV1 and PEFR (Table 1). Ninety two \% participants reported pungent smell, $72 \%$ throat congestion, $70 \%$ burning sensation in eyes, $60 \%$ headache, $52 \%$ nausea and $45 \%$ rhinorrhea (Table 2).

Table 1: Pulmonary Function Tests: pre and post exposure, AlIMS Rishikesh ( $\mathrm{N}=40)$.

\begin{tabular}{|c|c|c|c|c|c|c|}
\hline Parameters & \multicolumn{2}{|c|}{ Pre exposure } & \multicolumn{2}{|c|}{ Post exposure } & \multirow{2}{*}{ t value } & \multirow{2}{*}{ p value } \\
\hline & Mean & SD & Mean & SD & & \\
\hline FVC (L) & 3.56 & 0.93 & 3.6 & 0.88 & -0.8 & 0.42 \\
\hline FEV1(L) & 4.29 & 8.08 & 3.06 & 0.69 & 1 & 0.32 \\
\hline FEV1/FVC (\%) & 87.08 & 5.79 & 85.72 & 6.41 & 2.083 & 0.044 \\
\hline FEF $_{25-75}(\mathrm{~L})$ & 3.65 & 1.07 & 3.44 & 0.97 & 2.52 & 0.016 \\
\hline PEFR(L/sec) & 6.78 & 1.77 & 6.9 & 1.7 & -1.06 & 0.29 \\
\hline
\end{tabular}

Table 2: Subjective symptoms of participants, AlIMS Rishikesh ( $\mathrm{N}=40)$.

\begin{tabular}{|c|c|c|c|c|c|c|}
\hline CNS & Headache $(60 \%)$ & $\begin{array}{l}\text { Nausea } \\
(52.50 \%)\end{array}$ & $\begin{array}{c}\text { Vomiting } \\
(5 \%)\end{array}$ & $\begin{array}{c}\text { Drowsiness } \\
(12.5 \%)\end{array}$ & $\begin{array}{c}\text { Giddiness } \\
(20 \%)\end{array}$ & $\begin{array}{c}\text { Light } \\
\text { headedness } \\
(5 \%)\end{array}$ \\
\hline Eye & $\begin{array}{c}\text { Itching } \\
(35 \%)\end{array}$ & $\begin{array}{c}\text { Burning } \\
(70 \%)\end{array}$ & \multicolumn{2}{|c|}{$\begin{array}{c}\text { Lacrimation } \\
(50 \%)\end{array}$} & \multicolumn{2}{|c|}{$\begin{array}{c}\text { Reddening } \\
(20 \%)\end{array}$} \\
\hline Nose & $\begin{array}{l}\text { Pungent smell } \\
(92.50 \%)\end{array}$ & $\begin{array}{l}\text { Crusting } \\
(12.5 \%)\end{array}$ & \multicolumn{2}{|c|}{$\begin{array}{c}\text { Rhinorrhoea } \\
\qquad(45 \%)\end{array}$} & \multicolumn{2}{|c|}{$\begin{array}{c}\text { Sneezing } \\
(7.5 \%)\end{array}$} \\
\hline Throat & $\begin{array}{c}\text { Irritation } \\
(10 \%)\end{array}$ & $\begin{array}{l}\text { Dryness } \\
(22.5 \%)\end{array}$ & \multicolumn{2}{|c|}{$\begin{array}{c}\text { Coughing } \\
(30 \%)\end{array}$} & \multicolumn{2}{|c|}{$\begin{array}{c}\text { Congestion } \\
(72.50 \%)\end{array}$} \\
\hline
\end{tabular}




\section{DISCUSSION}

The acute exposure of fumes of embalming fluid was associated with significant reduction in FEV1/FVC ratio and $\mathrm{FEF}_{25-75 \%}$. The FEV1/FVC ratio decreased by $1.6 \%$, while $\mathrm{FEF}_{25-75 \%}$ by $5.8 \%$. The FEV1/FVC ratio is one of the well known markers of obstructive type of lung diseases[9]. $\mathrm{FEF}_{25-75 \%}$ flow rate is suggestive of anatomical region of mid-airway flow pathology[10]. In our study significant reduction in FEV1/FVC ratio and $\mathrm{FEF}_{25-75 \%}$ and no change in PEFR is suggestive of mild mid-airway obstruction after exposure to embalming fluid fumes.

Literature findings of formalin exposure and PFTs are varied and heterogeneous. Chia, et al studied 150 first-year medical students exposed to formaldehyde during the dissection of cadavers in a gross anatomy laboratory and reported no significant difference in the pre- and postexposure FEV1 and FVC values[11]. Khalif et al reported that FVC decreased in participants immediately after first exposure while all other lung function parameters remained unchanged [12].

Binawara reported decreased values of FVC, FEV1 and PEFR and no change in FEV1/FVC ratio and $\mathrm{FEF}_{25-75 \%}$ in male participants and all changes reverted back to normal within twenty four hours[13]. On the contrary, study by AkbarKhanzadeh, et al showed FVC to decrease while FEV1/FVC ratio to increase with exposure[14]. The varied and heterogeneous effect of formalin on PFTs may due to different study settings, differential exposure duration, procedure of recording PFTs, basal exterogenous pollutants in the atmosphere and other variables.

Formalin exposure is a proven hazard for asthmatics[15]. In our study nearly all participants reported symptoms related to eyes, nose, throat and nervous system. Literature reports that formalin exposure to concentration as low as 0.1 to $3.0 \mathrm{ppm}$ can cause burning of the eyes, increased lacrimation, and upper respiratory tract symptoms [16-18]. Higher levels (10-20 ppm) may produce cough, tightening in the chest, a sense of pressure in the head and exposures of 50-100 ppm or more can cause serious injury, including pulmonary edema, pneumonitis, or death [19]. During the cadaver dissection the personal exposure of formalin to the student is even more than average indoor concentration[20]. Therefore, we can infer in our experimental setting the reporting of cough, headache, eye and nose symptoms in significant number of participants is indirectly indicative of low to moderate level of formalin concentration in our dissection hall.

Formaldehyde has been classified by the International Agency for Research on Cancer (IARC) as "carcinogenic in humans" (class 1); however it is still widely used in anatomy and pathology departments for the fixing and conservation of biological tissues. Its use therefore raises the question of occupational hazard [21].

As the subject of anatomy is the foundation on which the whole medical curriculum would be laid down, health of first year medical students should not be compromised in dissection halls. The authors therefore suggest strict institutional policies to be formulated regarding proper ventilation and exhaust facilities in dissection halls, a regular assessment of formalin concentration and use of safer fixative agents like gluteraldehyde for cadaver preservation. Personal protective measures like masks containing activated carbon in dissection halls should be considered and practiced. Special screening and precautions are required for asthmatics and allergy prone medical students prior to the commencement of dissection classes.

\section{CONCLUSION}

The acute exposure to embalming fluid fumes during cadaver dissection by the first year medical students could be suggestive of pulmonary dysfunction owing to mid-airway obstruction and mucosal irritation. Guidelines for regulation of concentration and duration of exposure to embalming fluid fumes should be formulated and monitored in the dissection halls.

Source of support: Intramural research grant from AlIMS, Rishikesh.

\section{Conflicts of Interests: None}

\section{REFERENCES}

[1]. Brenner E. Human Body Preservation - Old and New Techniques. J. Anat 2014; 224:316- 344. 
[2]. Mysorekar VR, Zargar RK, Singh H. Embalming and Preservation of Cadavers: An All-India Survey. J Anat Soc India 1997; 26(3): 149-155.

[3]. Ajmani ML. Embalming Principals and Legal Aspects. $1^{\text {st }}$ ed. New Delhi, India: Jaypee Brothers Medical Publishers (P) Ltd. 1998:116-117.

[4]. Gichner T. IARC monographs on the evaluation of carcinogenic risks to humans. Wood dust and formaldehyde. Lyon, International Agency for Research on Cancer 1995; 6:217-362.

[5]. Dixit D, Athavia PD, Pathak HM. Toxic effects of embalming fluid on medical students and professionals. JIAFM 2005; 27(4):209-211.

[6]. Berbstein, RS, Staynedr LT, Elliott LJ, Kimbrough R. Inhalation exposure to formaldehyde: An overview of its toxicology, epidemiology, monitoring and control. Am. Ind. Hyg. Assoc. J 1984; 45:778-85.

[7]. Burge PS, Harries MG, Lam WK, O'Brien IM, Patchett PA. Occupational asthma due to formaldehyde 1985; Thorax; 40:255-60.

[8]. Shusterman D. The effects of Air Pollutants and Irritants on the Upper Airway. Proc Am Thorac Soc 2011; $8: 101-105$.

[9]. Lambert A, Drummond MB, Wei C, Irvin C, Kaminsky $D$, McCormack M, Wise R. Diagnostic accuracy of FEV1/forced vital capacity ratio z scores in asthmatic patients. J Allergy Clin Immunol 2015 Sep; 136(3):649-653.

[10]. Goel A, Goyal M, Singh R, Verma N, Tiwari S. Diurnal Variation in Peak Expiratory Flow and Forced Expiratory Volume. Journal of Clinical and Diagnostic Research 2015; 9(10):CC05-CC07.

[11]. Chia SE, Ong CN, Foo SC, Lee HP. Medical students' exposure to formaldehyde in a gross anatomy dissection laboratory. J Am Coll Health 1992; 41(3):1159.

[12]. Khaliq F, Tripathi P. Acute effects of formalin on pulmonary functions in gross anatomy laboratory. Indian J Physiol Pharmacol 2009; 53(1):93-6.

[13]. Binawara BK, Rajnee, Choudhary S, Mathur KC, Sharma H, Goyal K. Acute effect of formalin on pulmonary function tests in medical students. Pak J Physiol 2010; 6(2):8-10.
[14]. Akbar-Khanzadeh F, Mlynek JS. Changes in respiratory function after one and three hours of exposure to formaldehyde in non-smoking subjects. Occup Environ Med 1997; 54(5):296-300.

[15]. Sauder LR, Green DJ, Chalham MD, Kulle TJ. Acute pulmonary response of asthmatics to $3.0 \mathrm{ppm}$ formaldehyde Toxical Ind Health. 1987; 3:569-57.

[16]. Kurose T, Kodera H, Aoyama H, Kawamata S. Formaldehyde concentration in the air and in cadavers at the gross anatomy laboratory in Hiroshima University. Hiroshima J Med Sci 2004; 53: 33-7.

[17]. Schachter EN, Witek TJ Jr, Tosun T, Leaderer BP, Beck GJ. A study of respiratory effects from exposure to 2 ppm formaldehyde in healthy subjects. Arch Environ Health 1986; 41: 229- 239.

[18]. Gurburz N, Coskun Z K, Liman F A, Anil A, Turgut H B. The Evaluation of Formaldehyde Exposure in the Anatomy Laboratories and the Preventive Measures. GMJ 2016; 27:98-103.

[19]. Zenz C, Dickerson OB, Horvath E.P. Occupational Medicine. $3^{\text {rd }}$ Edi, St. Louis 1994; MO: 106.

[20]. Ohmichi, K, Komiyama M, Matsuno Y, Takanashi, Y, Miyamoto H, Kadot T, Maekawa M,Toyama, Y, Tatsugi Y, Kohno T, Ohmichi M, Mori, C. Formaldehyde exposure in a gross anatomy laboratory-personal exposure level is higher than indoor concentration. Environ. Sci. Pollut. Res. Int 2006; 13(2):120-4.

[21].Formaldehyde, 2-Butoxyethanol and 1-tertButoxypropan-2-ol, IARC Monographs on the Evaluation of Carcinogenic Risks to Humans, Lyon, France: International Agency for Research on Cancer 2006; 88:39-325.

$$
\begin{aligned}
& \text { How to cite this article: } \\
& \text { Rashmi Malhotra, Rajesh Kathrotia, Arun Goel, Yogesh Singh. } \\
& \text { EMBALMING FLUID- A POISONOUS PRESERVATION POTION: } \\
& \text { EFFECTS ON PULMONARY FUNCTIONS OF STUDENTS. Int J Anat } \\
& \text { Res } 2017 ; 5(2.2): 3809-3812 \text {. DOI: } 10.16965 / \text { ijar.2017.187 }
\end{aligned}
$$

